\title{
Evaluation and Enhancement of Available Micronutrients Status of Cultivated Soil of Nigeria Guinea Savanna Using Organic and Inorganic Amendments.
}

\author{
Oluwadare, D.A. ${ }^{1}$, Voncir, N. ${ }^{2}$, Mustapha, S. $^{2}$, Mohammed, G.U. ${ }^{2}$ \\ ${ }^{I}$ (Department of Soil Science, Federal University Oye - Ekiti, Nigeria) \\ ${ }^{2}$ (Department of Crop Production Programme, Abubakar Tafawa Balewa University, Bauchi, Nigeria)
}

\begin{abstract}
Field experiments were conducted during years 2010 and 2011 cropping seasons of Nigerian Guinea Savanna, in which eighty-one surface soils (0-20 cm depth) were collected before, in-between and after the cropping seasons. The soils were analysed for status of $\mathrm{pH}, \mathrm{OC}, \mathrm{CEC}$, available $\mathrm{Zn}, \mathrm{Cu}, \mathrm{Fe}$ and $\mathrm{Mn}$. Initial status of the soil $\mathrm{pH}, \mathrm{OC}$ and CEC were 5.7 (moderately acidic), $4.62 \mathrm{~g} \mathrm{~kg}^{-1}$ and $1.6 \mathrm{cmol}(+) / \mathrm{kg}$ respectively, while those of $\mathrm{Zn}, \mathrm{Cu}, \mathrm{Fe}$ and $\mathrm{Mn}$ were $0.18,0.1,22.5$ and $21.5 \mathrm{mg} \mathrm{kg}^{-1}$ respectively. The soils were deficient in all the studied properties except $\mathrm{Fe}$ and $\mathrm{Mn}$ which were in high concentrations in the soils. Applications of organic and inorganic amendments to the soils significantly improved soil properties through increment in the soil $\mathrm{pH}$ and organic carbon status. The effect of the inorganic amendment was immediate while that of the organic was on residual basis. By the end of the second season, status of $\mathrm{Zn}\left(0.75 \mathrm{mg} \mathrm{kg}^{-1}\right)$ and $\mathrm{Cu}(0.28 \mathrm{mg} \mathrm{kg}$ ${ }^{1}$ ) had significantly increased above the critical limit, from residual effect of application of $10 \mathrm{t} \mathrm{ha}^{-1}$ of fertiplus and compost plus respectively, while the excessively high concentrations of Fe and $\mathrm{Mn}$ in the soils were also amended.
\end{abstract}

Keywords- Amendment, Enhancement, Evaluation, Micronutrients, Savanna.

\section{Introduction}

Micronutrients are essential elements required by plants in very small amounts for growth and development. They include iron, zinc, copper, boron, manganese, molybdenum and chlorine. Micronutrients play a vital role in gene expression, biosynthesis of protein, nucleic acids, growth substances, metabolism of carbohydrates and lipids through their involvement in various plant enzymic systems and other physiologically active molecules (Rangel, 2003). Generally, studies on micronutrients status of Nigerian soils have been neglected in the past due to non- prevalence of their deficiency symptoms. This has made the information on soil micronutrient status of Nigeria savanna soils scanty. Lombin (1983), Kparmwang et. al. (1995) and Adeboye (2003), reported that limited studies have been conducted on the micronutrients status of soils within the savanna zone of Nigeria. However, the few investigations carried out so far have revealed micronutrient deficiency in some Nigerian savanna soils (Lombin (1983a, 1983b, 1985a). Depletion of micronutrients in Nigerian savanna soils has resulted from intensively cultivated soil with high nutrient-demanding crops, highly weathered rocks and leaching. Mustapha and Loks (2005), reported that the use of new high yielding crop varieties which are nutrient demanding have unraveled micronutrient deficiencies in some Nigeria Savanna soils.

In order to enhance the micronutrient status of these soils, there is need for assessment of their initial micronutrient status in order to integrate the appropriate soil fertility management that involves judicious use of combined organic and inorganic fertilizers. This is a feasible approach which has been employed in overcoming soil fertility constraints (Abedi et al., 2010; Kazemeini et al., 2010; Mugwe et al., 2009). However, availability and uptake of micronutrients are affected by the presence of the macro-nutrients present in these amendments due to either negative or positive interactions (Fageria, 2001). Hence, caution must be taken to avoid indiscriminate use of macronutrients-borne fertilizers. The addition of organic and mineral fertilizers to soil can create a beneficial interaction between macro and micro elements, thus supplying optimum levels of needed micronutrients. This has been reported to improve crop yield and quality and play a key role in the maintenance of soil productivity (Akande et al., 2006). This study was carried out to evaluate and improve upon the micronutrient status of Nigerian Guinea Savanna soil through organic and inorganic fertilizers application.

\section{Materials and Methods}

The study was conducted during 2010 and 2011 cropping seasons, at Bauchi, in the guinea savanna agro-ecological zone of Nigeria $\left(10^{\circ} 17^{\circ} \mathrm{N}\right.$ and $\left.9^{\circ} 49^{\circ} \mathrm{E}\right)$. The area is characterized by two distinct seasons, the rainy season lasting from May to October and the dry season from November to April. The mean annual rainfall is 1014.70 and the mean daily maximum temperature is $26^{\circ} \mathrm{C}$. 
Twenty-seven surface soil samples $(0-20 \mathrm{~cm})$, were collected from a maize field laid out in a randomized complete block design (RCBD) with three replications, thus giving a total of eighty-one soil samples for laboratory analyses. Each sample was a representative of a plot. The sample collections were done three times during the study; before cropping, after the first year harvest and after the second year harvest. Two organic fertilizers: fertiplus and compost plus with NPK 20:10:10 were employed. The manures were incorporated into the plots at specified rates of 0,5 and $10 \mathrm{tha}^{-1}$, while NPK was applied at 0,100 and $200 \mathrm{~kg}$ $\mathrm{ha}^{-1}$. In the year 2010 cropping season, the organics were incorporated into the soil and left for two weeks before maize was planted. This was to allow for early microbial breakdown of the locked-up nutrients in the manures. The NPK fertilizer was incorporated in the soil three weeks after planting the maize. In the year 2011 cropping season, the experiment was repeated and done as carried out in the first year, but without application of any treatment. The collected soil samples were tested for $\mathrm{pH}$, organic carbon, cation exchange capacity and available micronutrients.

The collected soil samples were air-dried and sieved through $2 \mathrm{~mm}$ sieve. Particle size distribution was determined using the hydrometer method as described by Bouyoucos (1981). Soil $\mathrm{pH}$ was determined in 1:1 soil water suspension with a glass electrode $\mathrm{pH}$ meter. Organic carbon was determined by the wet oxidation method (Walkley and Black, 1934). Cation Exchange Capacity (CEC) was determined by sodium acetate (NaOAc) saturation and neutral ammonium acetate. The available iron, zinc, copper and manganese were determined by atomic absorption flame photometer after extracting the soil with Diethylene Triamine Penta Acetic acid (DTPA) as described by Lindsay and Norvell (1978). Data collected was subjected to Analysis of Variance (ANOVA). Duncan's Multiple Range Test (DMRT) was used for mean separation at 5\% level of probability.

\section{Results and Discussion \\ 3.1 Particle Size Distribution of Soil at the Experimental Site}

Table 1 showed the initial particle-size distribution as well as the micronutrient status of the soil at the experimental site. The mean values of sand, silt and clay fractions were $76.67 \%, 14.56 \%$ and $8.77 \%$ respectively, giving the soil a sandy clay loam texture. This suggests that the soil would be prone to leaching due to the high presence of macro-pores of the dominating sand fraction. This could adversely affect the growth of crops because of probable low water and nutrient retention capacity which aid in high leaching of soil nutrients. Furthermore, due to intense and continuous cultivation as well as the sandy nature of the soils, cations such as $\mathrm{Ca}^{2+}, \mathrm{Mg}^{2+}$ and $\mathrm{K}^{+}$are continuously removed resulting into acidity as exhibited by the relatively low $\mathrm{pH}$ and CEC values of the soils of the research site. This invariably explains the reason for the observed low $\mathrm{pH}$, CEC and OC status of the soil.

\subsection{Initial Micronutrient Status of the Soil}

The initial micronutrient status of the soil had it that $\mathrm{Cu}$ and $\mathrm{Zn}$ contents were low, while $\mathrm{Fe}$ and $\mathrm{Mn}$ contents were very high (Table 1). This means that the soil was not deficient in Fe and Mn, hence fertilizers application to raise their levels was unnecessary. The soils were sufficient in both available Fe and $\mathrm{Mn}$, since their contents were more than the critical levels of 4.5 and $1 \mathrm{mg} \mathrm{kg}^{-1}$ respectively reported by Kparmwang, et.al. (2000) and Lindsay and Norvell (1978). The soils were all rated high ( $\mathrm{Fe}>10$ and $\mathrm{Mn}>5.0 \mathrm{mg} \mathrm{kg}^{-1}$ ) for both micronutrients (Kparmwang et. al., 2000). Kparmwang and Malgwi (1997); Lombin (1983); Cottenie et. al. (1981) and Maniyunda et. al. (2009) have also reported higher values of soil Fe and Mn in their study.

Several authors have indicated that the availability of micronutrients in soils depends on soil $\mathrm{pH}$. Generally, micronutrients, especially $\mathrm{Fe}$ and $\mathrm{Mn}$ have been known to increase with increasing soil acidity, as observed in this study. This is similar to findings of Brady and Weil (1999), who reported that in very acid soils, there is a relative abundance of Fe and Mn. On a global study, Sillanpää (1982) reported normal to excessive levels of Mn in a number of soils from Nigeria. Findings of this study agree with that of Lombin (1983), who earlier described the sandy leached Inceptisols and Ultisols or Oxisols of the Nigerian southern savanna and derived savanna as being low in available zinc. Lombin (1983) and Pam (1990) also reported that low zinc levels in the savannah soils of Nigeria was due to low levels of the element in the parent material, absence of the micronutrient in fertilizer programme, soil $\mathrm{pH}$ and leaching intensities. Enwezor et al. (1990), reported that $\mathrm{Cu}$ deficiencies are common in sandy soils, and that available Fe is generally high in tropical soils. The low CEC value which also conformed with low organic carbon and high iron content of the soil, could also be attributed to the presence of highly weatherable, low activity clay probably kaolinite, which is characterized with low charge density in the soil clay fraction, thus suggesting the soil under study to be an oxisol.

\subsection{Mineral Composition of the Organic Fertilizers}

Table 2 presented data on the nutrients composition of Fertiplus and compost plus. Both manures were high in organic carbon, nitrogen and potassium content, but low in phosphorus content. The low phosphorus content might be due to "phosphorus problem" as reported by Holford (1997), that generally, phosphorus in all 
its natural forms, including organic forms is very stable or insoluble and only a small proportion exists in the soil solution at any one time.

\subsection{Effects of Treatments on Selected Soil Properties and Available Micronutrients in the First and Second Year \\ 3.4.1 Soil $\mathrm{pH}_{\mathrm{w}}$}

Data presented in Table 3 showed that in first year, applications of fertiplus, compost plus and NPK 20:10:10 did not have significant effect $(\mathrm{P}>0.05)$ on soil $\mathrm{pH}$. However, in the second year, only applications of the organic fertilizers increased soil $\mathrm{pH}$ significantly (Table 4). Applications of fertiplus and compost plus at 10 $\mathrm{t} / \mathrm{ha}$ significantly reduced the soil acidity level from moderately acidic (at $\mathrm{pH}$ controls of 5.77 and 5.82) to slightly acidic- at $\mathrm{pH} 6.15$ and $\mathrm{pH} 6.08$ respectively. This was as a result of the residual effects of the organic fertilizers. This is in agreement with the findings of Jones \& Wild (1975) and Ngeze (1998), that organic manures act as buffering agent against undesirable soil $\mathrm{pH}$ fluctuations. The delayed performance of the manures in reducing soil acidity until the second year agreed with the findings of Ramamurthy and Shivashankar (1996), that, nutrients present in organic matter are not fully available to the crops in the season of its application. Munecheru-muna et. al. (2007); Nnabude and Mbagwu (2001), attributed the cause to slow decomposition rate of organic fertilizers, which produces lasting residual effects on soil properties.

\subsubsection{Organic Carbon}

As shown in Table 3 , fertiplus application at 10 t/ha increased soil organic carbon status significantly $(\mathrm{P}>0.05)$ to $7.87 \mathrm{~g} / \mathrm{kg}$ in the first year, although, there was no significant difference between fertiplus application at 5 t/ha and the control. The non-significance between their effects might be due to the uneven distribution of inherent organic carbon status across soil surface, which had complemented OC status in the control. Compost plus application also had significant effect on organic carbon with applications of 5 and 10 t/ha having significantly higher organic carbon than the control. Enhancement of organic carbon- increase in the first year could be due to the fast rate of organic matter breakdown by soil microbes in some plots under favorable soil climate. Application of NPK fertilizer did not have significant effect on organic carbon in the first year. The significantly higher values of OC gotten from the manures application over NPK application, was in agreement with findings of Melero Sanchez et. al. (2008), who reported that organically fertilized soils show significant increases in total organic carbon compared with those found under inorganically fertilized plots. Highest organic carbon values obtained from applications of fertiplus and compost plus in first year were $7.87 \mathrm{~g} / \mathrm{kg}$ and 7.02 $\mathrm{g} / \mathrm{kg}$ respectively, while they were $14.63 \mathrm{~g} / \mathrm{kg}$ and $14.32 \mathrm{~g} / \mathrm{kg}$ respectively in the second year. The higher value obtained from fertiplus application over compost application might be attributed to its higher organic carbon composition as presented in Table 2.

In the second year (Table 4), increasing application rates of fertiplus and compost plus increased soil organic carbon significantly $(\mathrm{P}>0.05)$. Applications of 5 and $10 \mathrm{t} / \mathrm{ha}$ of fertiplus raised soil organic carbon status to 12.02 and $14.63 \mathrm{~g} / \mathrm{kg}$ respectively, while applications of 5 and $10 \mathrm{t} / \mathrm{ha}$ of compost plus raised organic carbon status to $11.71 \mathrm{~g} / \mathrm{kg}$ and $14.32 \mathrm{~g} / \mathrm{kg}$ respectively. Application of NPK fertilizer at 5 and $10 \mathrm{t} / \mathrm{ha}$ also produced significantly higher organic carbon than the control. It was observed that the increasing effect of the applied manures in the second year doubled the first year effect. This observation is in agreement with the reports of Adenawoola and Adejoro (2005) that the cumulative agronomic value of some organic manure applied to agricultural soils could be more than five times greater in the post-application period than the value realized during the year of application. The organic carbon increment observed in the second year was as a result of residual effect of the manures applied in the first year.

\subsubsection{Cation Exchange Capacity}

As presented in Table 3, for the first cropping season, increasing application rates of each treatment increased soil CEC significantly ( $\mathrm{P}>0.05$ ) above the control, although, not above the critical limit theorized by Esu (1991). Across all treatment levels, the highest CEC value of $5.41 \mathrm{cmol}(+) / \mathrm{kg}$ was gotten, from application of $10 \mathrm{t} / \mathrm{ha}$ of Fertiplus. Increasing rates of NPK application also increased the CEC significantly in the first year. This might be as a result of quick mineralization of the directly applied NPK fertilizer which added to the pool of soil cations, thereby enhancing their capacity for ionic exchange.

In the second year (Table 4), all the treatments rates significantly improved soil CEC above the control. Applications of $10 \mathrm{t} / \mathrm{ha}$ of fertiplus and compost plus gave CEC values of 6.62 and $6.21 \mathrm{cmol}(+) / \mathrm{kg}$ respectively, while $100 \mathrm{~kg} / \mathrm{ha}$ of NPK produced $5.80 \mathrm{cmol}(+) / \mathrm{kg}$. The soil CEC was increased above the critical limit by the residual effects of the applied organic fertilizers. The more significant effect observed from the application of these manures was due to the increase in humic substances or soil organic matter decomposition which increased negatively charged sites for soil's cation attraction and exchange, thus enhancing nutrients 
availability in the soil. This agrees with findings of Jones \& Wild (1975) and Ngeze (1998), who reported that organic manure enhances cation exchange capacity.

\subsubsection{Available Micronutrients $(\mathrm{Zn}, \mathrm{Cu}, \mathrm{Fe} \& \mathrm{Mn})$}

In the first cropping season, effect of fertiplus on soil $\mathrm{Zn}$ status was not significant, while those of compost plus and NPK brought significant increase in $\mathrm{Zn}$ status. In the second year, application of each treatment increased Zn status significantly, with the highest increment of $0.75 \mathrm{mg} / \mathrm{kg}$ being gotten from $10 \mathrm{t} / \mathrm{ha}$ of fertiplus application. This agrees with findings of Lombin (1983); Kparmwang et. al. (1998); Mustapha and Singh (2003), who reported that organic matter serves as the main reservoir of plant available zinc in Nigeria savanna soils in view of the small amount of clay content. The second year increment in $\mathrm{Zn}$ status from the organo-minerals application was due to the residual effect of the organic fertilizers.

Soil $\mathrm{Cu}$ status was raised by the application of each treatment in the first year, but not up to the critical limit of $0.2 \mathrm{mg} / \mathrm{kg}$ reported by Esu (1991). In the second year, there was a steady increase in $\mathrm{Cu}$ status with increasing application rates of each treatment. Sole applications of $10 \mathrm{t} / \mathrm{ha}$ fertiplus, $10 \mathrm{t} / \mathrm{ha}$ compost plus and $200 \mathrm{~kg} / \mathrm{ha}$ NPK raised $\mathrm{Cu}$ status to $0.27,0.28$ and $0.26 \mathrm{mg} / \mathrm{kg}$ respectively (Table 4). The slow increase in $\mathrm{Zn}$ and $\mathrm{Cu}$ status from first through the second year, could be attributed to the slowness of organic manures in reducing soil acidity due to their late start in nutrient release. In the case of NPK fertilizer, its application could not have been expected to have a lasting effect on the soil due to its immediate mineralization upon direct application in the first year.

In the first year, increasing application rates of NPK fertilizer increased Fe status significantly, while the organic fertilizers significantly reduced Fe status below control (Table 3). In the second year, NPK fertilizer had no significant effect on soil $\mathrm{Fe}$, while increasing application rates of fertiplus and compost plus significantly reduced Fe status below the control (Table 4). The decrease in soil Fe status in the second year, was due to the increased soil pH from residual effect of the applied manures. Mckenzie (2003), reported that the availability of $\mathrm{Fe}$ tend to decrease as $\mathrm{pH}$ increases. The responsible mechanism for this, might be the formation of low solubility compounds as also reported by Akporhonor and Agbaire (2009). Through both years, the resulting Fe status was still in the high rating $(\mathrm{Fe}>10)$ as reported by Kparmwang et. al. (2000).

None of the treatments produced significant effect on soil Mn in the first year, except $10 \mathrm{t} / \mathrm{ha}$ fertiplus application which significantly reduced $\mathrm{Mn}$ status below the control (Table 3). Just like the observed trend for $\mathrm{Fe}$ in the second year (Table 4), soil Mn was also significantly decreased by the residual effects of both organic fertilizers. The increase in the soil micronutrient status in the second year was as a result of residual effect of fertiplus and compost plus.

Table 1: Physical and chemical properties of the soil at the experimental site before the experiment

\begin{tabular}{lcc}
\hline Nutrients & Values & \multicolumn{1}{c}{ Status* } \\
\hline pH $\left(1: 1 \mathrm{H}_{2} 0\right)$ & 5.7 & Moderately acidic \\
Sand $\%$ & 76.67 & \\
Silt $\%$ & 14.56 & \\
Clay $\%$ & 8.77 & \\
Textural class & Sandy Clay Loam & \\
OC g/kg & 4.62 & Low \\
$\mathrm{CEC} \mathrm{cmol(+)/kg}$ & 1.6 & Low \\
Exchangeable Cu mg kg-1 & 0.1 & Low \\
Exchangeable $\mathrm{Zn} \mathrm{mg} \mathrm{kg}$ & 0.18 & Low \\
Exchangeable Fe mg kg & 22.5 & High \\
Exchangeable Mn mg kg & High \\
\hline
\end{tabular}

*Source: Esu (1991)

Table 2: Nutrient composition of Fertiplus and Compost plus (Organic Fertilizers)

\begin{tabular}{|c|c|c|c|}
\hline Nutrient & & values & \\
\hline & Fertiplus & Compost plus & Percentage Difference \\
\hline Organic carbon $\mathrm{g} / \mathrm{kg}$ & 39.64 & 32.50 & $22 \%$ \\
\hline $\mathrm{N} \mathrm{g} / \mathrm{kg}$ & 4.22 & 3.92 & $8 \%$ \\
\hline $\mathrm{P}_{2} \mathrm{O}_{5} \mathrm{mg} \mathrm{kg}^{-1}$ & 2.96 & 2.60 & $14 \%$ \\
\hline $\mathrm{K}_{2} \mathrm{O} \mathrm{cmol}(+) / \mathrm{kg}$ & 2.83 & 1.99 & $42 \%$ \\
\hline $\mathrm{C} / \mathrm{N}$ ratio & 9.4 & 8.3 & $13 \%$ \\
\hline
\end{tabular}


Table 3:Effects of treatment on available micronutrients of soil in 2010.

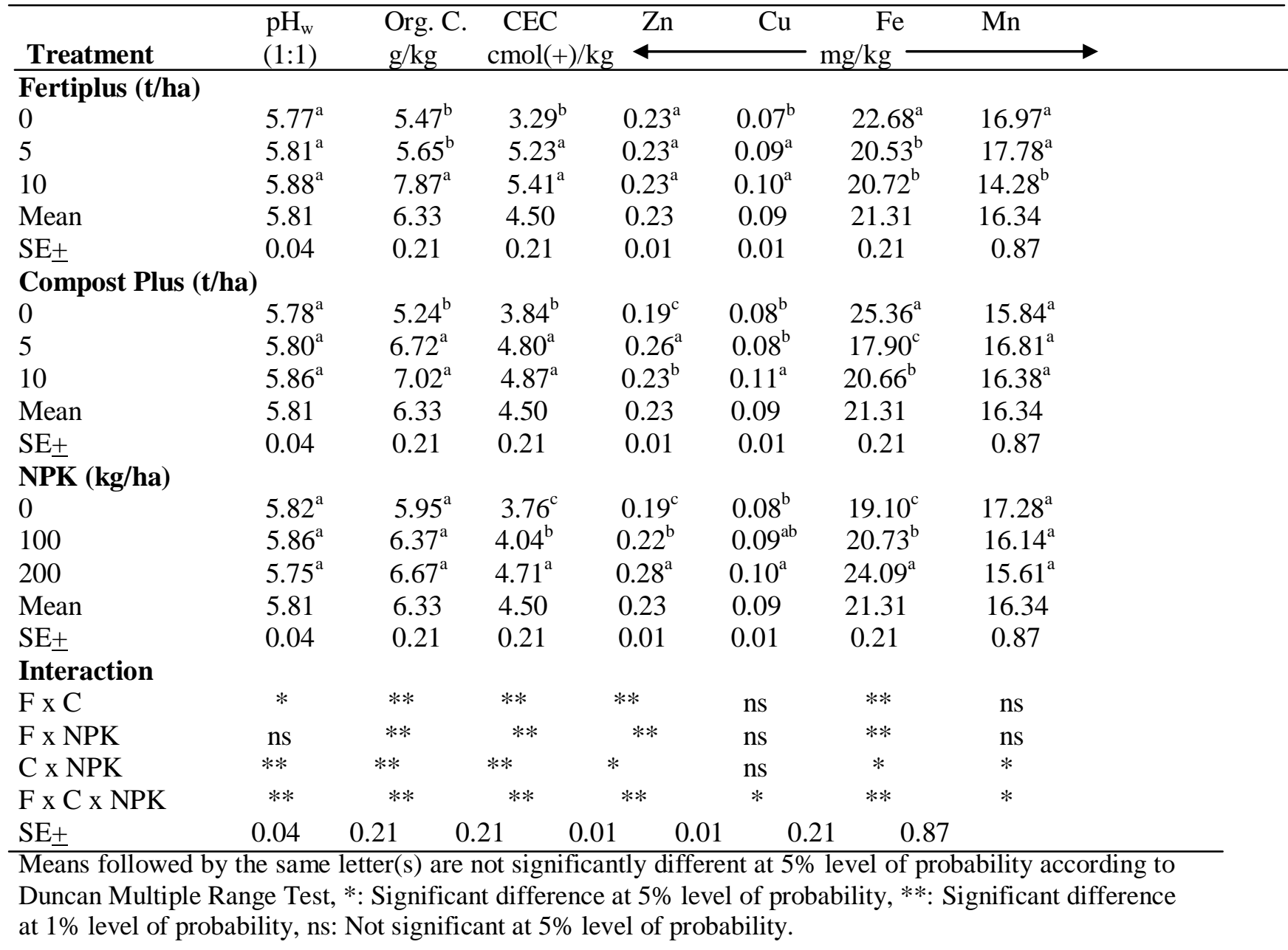

Table 4: Effects of treatment on available micronutrients of soil in 2011.

\begin{tabular}{|c|c|c|c|c|c|c|c|}
\hline Treatment & $\begin{array}{l}\mathrm{pH}_{\mathrm{w}} \\
(1: 1)\end{array}$ & $\begin{array}{l}\text { Org. C. } \\
\text { g/kg }\end{array}$ & $\begin{array}{c}\mathrm{CEC} \\
\mathrm{cmol}(+) / \mathrm{kg}\end{array}$ & $\mathrm{Zn}$ & $\mathrm{Cu}$ & $/ \mathrm{kg}$ & $\mathrm{Mn}$ \\
\hline \multicolumn{8}{|c|}{ Fertiplus (t/ha) } \\
\hline 0 & $5.77^{\mathrm{b}}$ & $8.78^{\mathrm{c}}$ & $4.19^{\mathrm{c}}$ & $0.29^{\mathrm{b}}$ & $0.15^{\mathrm{c}}$ & $22.53^{\mathrm{a}}$ & $34.21^{\mathrm{a}}$ \\
\hline 5 & $6.02^{\mathrm{a}}$ & $12.02^{\mathrm{b}}$ & $5.74^{\mathrm{b}}$ & $0.30^{\mathrm{b}}$ & $0.19^{b}$ & $19.12^{\mathrm{b}}$ & $31.59^{c}$ \\
\hline 10 & $6.15^{\mathrm{a}}$ & $14.63^{\mathrm{a}}$ & $6.62^{\mathrm{a}}$ & $0.75^{\mathrm{a}}$ & $0.27^{\mathrm{a}}$ & $15.97^{\mathrm{c}}$ & $32.12^{\mathrm{b}}$ \\
\hline Mean & 5.98 & 11.81 & 5.52 & 0.45 & 0.20 & 19.20 & 32.64 \\
\hline $\mathrm{SE} \pm$ & 0.08 & 0.12 & 0.12 & 0.03 & 0.00 & 0.74 & 0.19 \\
\hline \multicolumn{8}{|c|}{ Compost Plus (t/ha) } \\
\hline 0 & $5.82^{\mathrm{b}}$ & $9.40^{\mathrm{c}}$ & $4.82^{\mathrm{c}}$ & $0.35^{\mathrm{b}}$ & $0.14^{\mathrm{c}}$ & $20.76^{\mathrm{a}}$ & $36.39^{\mathrm{a}}$ \\
\hline 5 & $6.04^{\mathrm{a}}$ & $11.71^{\mathrm{b}}$ & $5.54^{\mathrm{b}}$ & $0.36^{\mathrm{b}}$ & $0.19^{\mathrm{b}}$ & $19.73^{\mathrm{a}}$ & $28.42^{\mathrm{c}}$ \\
\hline 10 & $6.08^{\mathrm{a}}$ & $14.32^{\mathrm{a}}$ & $6.21^{\mathrm{a}}$ & $0.64^{\mathrm{a}}$ & $0.28^{\mathrm{a}}$ & $17.12^{\mathrm{b}}$ & $33.11^{\mathrm{b}}$ \\
\hline Mean & 5.98 & 11.81 & 5.52 & 0.45 & 0.20 & 19.20 & 32.64 \\
\hline $\mathrm{SE}_{ \pm}$ & 0.08 & 0.12 & 0.12 & 0.03 & 0.00 & 0.74 & 0.19 \\
\hline \multicolumn{8}{|c|}{ NPK (kg/ha) } \\
\hline 0 & $5.96^{\mathrm{a}}$ & $10.30^{\mathrm{b}}$ & $4.88^{\mathrm{b}}$ & $0.32^{\mathrm{c}}$ & $0.17^{\mathrm{b}}$ & $18.97^{\mathrm{a}}$ & $30.84^{\mathrm{c}}$ \\
\hline 100 & $5.92^{\mathrm{a}}$ & $12.67^{\mathrm{a}}$ & $5.80^{\mathrm{a}}$ & $0.40^{\mathrm{b}}$ & $0.17^{b}$ & $19.65^{\mathrm{a}}$ & $32.24^{\mathrm{b}}$ \\
\hline 200 & $6.05^{\mathrm{a}}$ & $12.46^{\mathrm{a}}$ & $5.59^{\mathrm{a}}$ & $0.62^{\mathrm{a}}$ & $0.26^{\mathrm{a}}$ & $18.99^{\mathrm{a}}$ & $34.84^{\mathrm{a}}$ \\
\hline Mean & 5.98 & 11.81 & 5.52 & 0.45 & 0.20 & 19.20 & 32.64 \\
\hline $\mathrm{SE} \pm$ & 0.08 & 0.12 & 0.12 & 0.03 & 0.00 & 0.74 & 0.19 \\
\hline
\end{tabular}




\begin{tabular}{|c|c|c|c|c|c|c|c|}
\hline $\mathrm{F} \times \mathrm{C}$ & $* *$ & $* *$ & $* *$ & $* *$ & $* *$ & $* *$ & $* *$ \\
\hline $\mathrm{F} \times \mathrm{NPK}$ & $* *$ & $* *$ & $* *$ & $* *$ & $* *$ & $* *$ & $* *$ \\
\hline C x NPK & $* *$ & $* *$ & $* *$ & $* *$ & $* *$ & $* *$ & $* *$ \\
\hline $\mathrm{F} \times \mathrm{C}$ x NPK & $* *$ & $* *$ & $* *$ & $* *$ & $* *$ & $* *$ & $* *$ \\
\hline $\mathrm{SE}+$ & 0.08 & 0.12 & 0.12 & 0.03 & 0.00 & 0.74 & 0.19 \\
\hline
\end{tabular}

Means followed by the same letter(s) are not significantly different at 5\% level of probability according to Duncan Multiple Range Test, *: Significant difference at 5\% level of probability, **: Significant difference at $1 \%$ level of probability, ns: Not significant at $5 \%$ level of probability.

\section{Conclusion}

The results obtained from this study have shown that, out of the four soil micronutrients namely, $\mathrm{Zn}$, $\mathrm{Cu}, \mathrm{Fe}$, and $\mathrm{Mn}$ under study, only $\mathrm{Zn}$ and $\mathrm{Cu}$ were deficient while $\mathrm{Fe}$ and $\mathrm{Mn}$ were in high concentrations in the soil. On immediate basis, mineral fertilizer significantly improved soil properties except for soil $\mathrm{pH}$ and organic carbon. Residual effect of the applied organic matter from organic sources significantly reduced soil acidity, thus improving soil $\mathrm{OC}, \mathrm{CEC}, \mathrm{Zn}$ and $\mathrm{Cu}$ than did mineral fertilizer. Since iron and manganese status of the soil were already high, future deficiency in both nutrients are unlikely. There is therefore, the need to formulate organo-mineral amendments that would improve soil properties and enhance in particular, $\mathrm{Cu}$ and $\mathrm{Zn}$ availability in Nigerian savannah soils.

\section{References}

[1] Rangel Z. (2003). Heavy metals as essentials nutrients. In: Prasad MNV, Hagemeyer J (eds) ; Heavy metal stress in plants : Molecules to Ecosystems. Springer-Verlag, Berlin, Heidelberg, pp. 271-294.

[2] Lombin, G., 1983. Evaluating the micronutrient fertility of Nigeria semi-arid Savanna soils: Zinc Soils. Soil Sci., 136: $42-47$.

[3] Kparmwang, T., Chude, V.O. and Esu, I.E. 1995. Hydrochloric acid (0.1M) and DPTA extractable and total iron manganese in basaltic soil profiles of the Nigerian savanna. Communications Soil Science Plant Analysis. 26 : 2783 -2796.

[4] Adeboye, M.K.A. (2003). Micronutrients Status of the soil of the Lower Gongola River Basin:Manganese and Copper. Spectrum Journal. $10: 57-64$.

[5] Lombin, G. (1983a). Evaluating the micronutrient fertility of Nigerian Semi - Arid Savanna Soils: Zinc Soils. SoilScience.136, 42 47.

[6] Lombin, G. 1983b. Evaluating the micronutrients fertility of Nigeria's semi-arid savanna soils. II Zinc. Soil Science 136: $42-47$.

[7] Lombin, G. 1985a. Evaluating the micronutrient fertility of Nigeria semi-arid savanna soils. Boron and Molybdenum. Soil Science Plant Nutrition. 13:12-25.

[8] Mustapha S, Loks, N.A. (2005). Distribution of available zinc, copper, iron and manganese in the fadama soils from two distinct agroecological zones in Bauchi State, Nigeria. J. Environ. Sci., 9(2): 22-28.

[9] Abedi T, Alemzadeh A, KazemeIni SA (2010) Effect of organic and inorganic fertilizers on grain yield and protein banding pattern of wheat. Australian Journal of Crop Science 4: 384-389.

[10] Kazemeini SA, Hamzehzarghani H, Edalat M (2010). The impact of nitrogen and organic matter on winter canola seed yield and yield components. Aust J Crop Sci 4: 335- 342.

[11] Mugwe J, Mugendi D, Kungu J, Muna M-M (2009) Maize yields response to application of organic and inorganic input under onstation and on-farm experiments in central Kenya. Exp. Agric 45: 47-59.

[12] Fageria, V. D. (2001). Nutrient Interactions in Crop Plants. Journal of Plant Nutrition, 24 (8) : $1269-1290$.

[13] Akande MO, Oluwatoyinbo FI, Kayode CO, Olowokere FI (2006). Response of maize (Zea mays) and Okra intercrop relayed with cowpea (Vigna unguiculata) to different levels cow dung amended phosphate rock. World J. Agric. Sci., 2 (1): $119-122$.

[14] Bouyocus, C.J. 1981. Hydrometer method improved for making particle size analysis of soil. Soil Sci. Soc. Proc. 26: 446-465.

[15] Walkley, A. and C.A. Black, 1934. An examination of the Degganett method for determining soil organic matter and a proposed modification of chromic acid titration method. Soil Sci., 39: 29-38.

[16] Lindsay, W.L. and Norvell, W.A. (1978). Development of DTPA soil test for zinc, iron, manganese and copper. Soil Science Society of America Journal. 42: 421-428.

[17] Kparmwang, T., Chude, V.O., Raji, B.A. and Odunze, A.C. 2000. Extractable micronutrients in some soils developed on sandstone and shale in the Benue - Valley, Nigeria. Nigerian Journal Soil Research. 1: 42-48.

[18] Kparmwang, T. and Malgwi, W.B. 1997. Some available micronutrients in profiles of ultisols and entisols developed from sandstone in north-western Nigeria. In: Singh, B.R. (ed.) Management of marginal lands in Nigeria. Proceedings of the 23rd annual Conference of Soil Science Society of Nigeria. 2nd- 5th March, 1997. Pp. 245 - 253.

[19] Cottenie, A.B.T., Kickens, L. and Sajjapongse, A. (1981). Micronutrient Status. In: Characterization of soil in Humid Tropics. D.J. Greenland (ed). Oxford University Press. Oxford. pp 149-163.

[20] Maniyunda, L. M., Kparmwang T. and Esu, I.E. 2009. Pedogenetic Evaluation of Chemical Properties, Extractable Iron And Manganese in Basaltic Soils of Kagoro, Nigeria. JATRUD, Vol. 1: Pp1-8

[21] Brady, N.C. and Weil, R.R. 1999. The nature and properties of soil. 12th edition. Prentice Hall, New Jersey, USA. 881 pp.

[22] Sillanpää, M. 1982. Micronutrients and the nutrient status of soils. A Global Study, FAO Soils Bulletin. No. 48. FAO, Rome, Italy.

[23] Pam, S.G. 1990. Correlation and calibration studies for Zn recommendation on maize (Zea mayz L.) in some upland soils of Northern Nigeria. M.Sc. Thesis, Faculty of Agriculture. ABU, Zaria, Nigeria. 127 p

[24] Enwezor, W.O., E.J. Udo, K.A. Ayotade, J.A. Adepetu and V.O. Chude, 1990. A review of soil and fertilizer use in nigeria. In FPDD. Literature review on soil fertility investigations in Nigeria. (Volume 5 North West Zone). Federal Ministry of Agriculture and Natural Resources, Lagos, pp: 241-281.

[25] Holford, I. C. R. 1997. Soil Phosphorus: its measurement, and its uptake by plants. Aust. J Soil Res. 35: 227 - 239.Jones, M.J. and Wild, A. 1975. The organic matter content of savanna soils of West Africa. Journal Soil Science. 24:42-53.

[26] Jones MJ. and Wild A, 1975. Soil of the West African Savanna. Commonwealth Bureau of Soil Harpenden. Technical Communication No.55. 
[27] Ngeze P.B., 1998. Learn how to make and use compost manure in farming. Friend-of-the-Book Foundation, Nairobi, Kenya. 45 Pp.

[28] Ramamurthy, V. and Shivashankar, K. 1996. Residual effect of organic matter and phosphorus on growth, yield and quality of maize (Zea mays). Indian Journal of Agronomy 41: $247-251$.

[29] Munecheru-muna, M., D. Mugendi, J. Kung`u, J. Mugwu and A. Bationo, 2007. Effects of Organic and Mineral fertilizer inputs on maize yield and soil chemical properties in a maize cropping system in meru south district, Kenya. Agro-forest system , 69: 189197.

[30] Nnabude, P.C. and J.S.C. Mbagwu, 2001. Physicochemical properties and productivity of a Nigerian typic-Haplustult amended with fresh and burnt rice-mill wastes. Biore. Technol., 76: 265-272.

[31] Melero Sanchez, S., Madejon E., Herencia, J.F., Ruiz-Porras, J.C. (2008). Longerm study of properties of a Xerofluvent and Guadalquivir River Valley under organic fertilization. Agronomy Journal 100:611-618.

[32] Adenawoola, A.R and Adejoro, S.A. (2005) Residual effects of poultry manure and NPK fertilizer residues on soil nutrients and performance of Jute (Corchorus olitorus L). Nigerian Journals of Soil Science 15:133-135.

[33] Esu, I. E.(1991). Detailed soil survey of National Horticultural Research Institute (NIHORT) Farm at Bunkure, Kano State, Nigeria. Institute for Agricultural Research, Ahmad Bello University, Zaria, Nigeria. $72 \mathrm{Pp}$.

[34] Kparmwang, T., Esu, I.E. and Chude, V.O. (1998). Available and total forms of copper and zinc in basaltic soils of the Nigerian savanna. Communication in Soil Science and Plant Analysis. 29 (15/16): 2235-2245.

[35] Mustapha, S. and Singh, B.R. (2003). Available zinc, copper, iron and manganese status of the basement complex rock-derived Ultisols in Bauchi State, Nigeria: A case study. Nigerian Journal of Soil Research. 4, 35-40.

[36] Mckenzie, R.H. (2003). Soil and Plant Nutrients. Agriculture, Food and Rural Development pp.1-4.

[37] Akporhonor, E. E. and Agbaire, P. O. (2009). Physiochemical properties and micronutrients status of farmland soils in Abraka, Nigeria. African Journal of Pure and Applied Chemistry Vol. 3 (7), pp. 131-134. 